\title{
FACTORS AFFECTING HEALTHY BEHAVIOR AMONG PRIMARY SCHOOL CHILDREN: APPLICATION OF HEALTH BELIEF MODEL
}

\author{
Frida Indriani'), Pawito²), Eti Poncorini Pamungkasari3) \\ ${ }^{1)}$ Masters Program in Public Health, Universitas Sebelas Maret \\ 2)Faculty of Social and Political Sciences, Universitas Sebelas Maret \\ 3)Faculty of Medicine, Universitas Sebelas Maret
}

\begin{abstract}
Background: Schools can be an effective institution for developing healthy practices in children. Children in primary schooling age can learn and get used to specific healthy behaviors, such as washing hands, brushing teeth, eating vegetables, etc. This study aimed to determine factors affecting healthy behavior among primary school children using Helth Belief Model.

Subjects and Method: A cross-sectional study was conducted at 25 primary schools in Nganjuk, East Java, from August to December 2019. A sample of 200 primary school students aged 6-12 years was selected by stratified random sampling. The dependent variable was healthy behavior. The independent variables were perceived susceptibility, perceived seriousness, perceived benefit, cues to action, and self-efficacy. The data were collected by questionnaire and analyzed by a multiple linear regression run on Stata 13 . Results: Healthy behavior in primary school students was improved by high perceived susceptibility $(b=1.11 ; 95 \% \mathrm{CI}=0.36$ to $1.85 ; \mathrm{p}=0.004)$, high perceived seriousness $(\mathrm{b}=$ $0.66 ; 95 \% \mathrm{CI}=-0.06$ to $1.38 ; \mathrm{p}=0.075)$, strong perceived benefit $(\mathrm{b}=0.64 ; 95 \% \mathrm{CI}=-0.86$ to $1.36 ; \mathrm{p}=0.084)$, cues to action $(\mathrm{b}=0.98 ; 95 \% \mathrm{CI}=0.26$ to $1.71 ; \mathrm{p}=0.008)$, and strong self-efficacy $(b=1.4 ; 95 \% \mathrm{CI}=0.74$ to $2.20 ; \mathrm{p}<0.001)$.

Conclusion: Healthy behavior in primary school students is improved by high perceived susceptibility, high perceived seriousness, strong perceived benefit, cues to action, and strong self-efficacy.
\end{abstract}

Keywords: clean and healthy behavior, health belief model

Correspondence:

Frida Indriani. Masters Program in Public Health, Universitas Sebelas Maret. Jl. Ir. Sutami 36A, Surakarta 57126, Central Java, Indonesia. Email: nersfrida15@gmail.com. Mobile: 082226327646

The $7^{\text {th }}$ International Conference on Public Health

Solo, Indonesia, November 18-19, 2020 | 174 https://doi.org/10.26911/the7thicph.02.63 